\title{
Identifikasi Hama dan Aplikasi Bioinsektisida pada Belalang Kembara (Locusta migratoria, L) sebagai Model Pengendalian Hama Terpadu pada Tanaman Sorgum
}

\author{
Nikolas Nik ${ }^{a}$, Aloysius Rusae ${ }^{b}$, dan Blasius Atini ${ }^{c}$ \\ ${ }^{a}$ Fakultas Pertanian, Universitas Timor, Kefamenanu, TTU - NTT, Indonesia. \\ ${ }^{b}$ Fakultas Pertanian, Universitas Timor, Kefamenanu, TTU - NTT, Indonesia. \\ ${ }^{c}$ Fakultas Ilmu Pendidikan, Universitas Timor, Kefamenanu, TTU - NTT, Indonesia
}

\section{Article Info}

\section{Article history:}

Received 4 Desember 2016

Received in revised form 20 Maret 2017 Accepted 9 Juni 2017

Keywords:

Sorghum bicolor $\mathrm{L}$

Metarizhium anisopliae, $\mathrm{L}$

Locusta migratoria, $\mathrm{L}$

\section{Pendahuluan}

Sorgum (Sorghum bicolor L.) adalah tanaman serealia yang potensial untuk dibudidayakan dan dikembangkan, khususnya pada daerah-daerah marginal dan kering di Indonesia misalnya Propinsi Nusa Tenggara Timur, Nusa Tenggara Barat dan Jawa Timur. Keunggulan sorgum terletak pada daya adaptas agroekologi yang luas dan tahan terhadap kekeringan. Tanaman sorgum memiliki kandungan nutrisi yang tinggi, sehingga sangat baik untuk digunakan sebagai sumber bahan pangan maupun pakan ternak alternatif. Tanaman ini telah lama dibudidayakan dan banyak dikenal oleh petani Indonesia khususnya d daerah Kepulauan Nusa Tenggara. Di NTT tanaman ini disebut sebagai jagung Rote, di Jawa disebut Cantel. Tanaman sorgum ini juga menjadi bahan makanan pokok bagi masyarakat NTT dan khusus di ketiga kabupaten yang ada di daratan Pulau Timor (Kabupaten Timor Tengah Utara, Belu dan Malaka). Tanaman in sebagai alternatif pengganti beras dan jagung. Biasanya ditanam secara tumpang sari dengan tanaman pangan lainnya.

Masyarakat di Nusa Tenggara Timur menganggap tanaman sorgum merupakan tanaman prioritas kedua setelah jagung. Tanaman ini cocok untuk lahan-lahan marjinal seperti curah hujan sangat singkat, sistem irigasi terbatas dan kondisi lahan kurang subur. Selain itu tanaman sorgum difungsikan sebaga pakan ternak khususnya pada wilayah kabupaten yang memiliki usaha ternak.

Tanaman sorgum (Sorghum bicolor, L.) dapat berproduksi walaupun dibudidayakan di lahan kurang subur, dan kecukupan air yang terbatas, masukkan (input) yang rendah, bahkan di lahan yang berpasir pun sorgum dapa di budidayakan. Tanaman ini mempunyai daya adaptasi yang luas dan mempunyai ragam manfaat yang tinggi. Biji sorgum dapat dipakai untuk: (1) makanan pengganti beras, bahan baku roti, industri makanan ringan; (2) bahan baku industri lem dan industri minuman (bir); (3) bahan baku industri pakan ternak; (4) bahan baku untuk media jamur merang (mushroom) dan jamur kayu (5) bahan baku untuk monosodium glutamate (MSG). Sedangkan batang dan daun dapat dipakai untuk hijauan makanan ternak. Sorgum manis dapat diproses menjadi gula atau bahan baku industri alkohol, dan industri minyak. Sorgum juga merupakan serealia yang potensial untuk digunakan sebagai substitusi beras karena kandungan gizinya setara (Sirrapa, 2003).

Keunggulan tanaman sorgum adalah, secara fisiologis sorgum memilik permukaan daun yang mengandung lapisan lilin dan sistem perakaran yang ekstensif dan dalam sehingga konsumsi terhadap absorpsi dan pemanfaatan air sangat efisien. Keunggulan lain dari tanaman sorgum memiliki keunggulan sistem ratun, dalam sekali masa penanaman dapat dipanen dua hingga tiga kal sehingga dapat mengurangi beban tenaga kerja. Bentuk tanaman ini secara umum hampir mirip dengan jagung, yang membedakan adalah tipe bunga, dimana jagung memiliki bunga tidak sempurna, sedangkan sorgum memiliki bunga sempurna. Pada daun sorgum terdapat lapisan lilin yang ada pada lapisan epidermisnnya. Adanya lapisan lilin tersebut menyebabkan tanaman sorgum mampu bertahan hidup pada daerah dengan kelembaban yang sangat rendah Lapisan lilin tersebut menyebabkan tanaman sorgum mampu hidup dalam cekaman kekeringan. Selama pertumbuhannya, tanaman menghendaki keadaan suhu udara antara $20-25^{\circ} \mathrm{C}$, cukup sinar matahari dan kelembaban udara yang cukup tinggi (Rukmana, 1994).

Produksi sorgum masih sangat rendah, khususnya di tingkat petani di NTT hanya berkisar $1 \mathrm{t} /$ ha (Batan Teknologi, 2013). Salah satu faktor penyebab rendahnya produksi ini antara lain adanya serangan organisme pengganggu tanaman terutama dari golongan serangga sehingga menyebabkan terjadinya kehilangan hasil cukup tinggi.

Belalang kembara (Locusta migratoria, L) merupakan salah satu hama penting di Indonesia yang terdapat di beberapa propinsi yaitu Nusa Tenggara Timur, Sulawesi Utara, Sulawesi Tenggara, Lampung, Sumatera Selatan, Kalimantan Tengah dan Kalimantan Barat. Hama ini merupakan salah satu faktor penghambat dalam program peningkatan produksi tanaman. Kerusakan dan kerugian yang ditimbulkan oleh hama belalang kembara sangat bervariasi diikut dengan peningkatan populasi yang tinggi. Belalang ini cenderung untuk membentuk kelompok besar dan suka berpindah-pindah sehingga dalam waktu yang singkat dapat menyebar pada areal yang luas. Kelompok yang bermigrasi dapat memakan tumbuhan yang dilewatinya selama dalam perjalanan. Perilaku makan belalang kembara dewasa biasanya hinggap waktu sore hari dan malam hari sampai pagi hari sebelum terbang. Kelompok nimfa yang bermigrasi dapat memakan tumbuhan di lokasi selama dalam perjalanan. Belalang ini lebih cenderung memilih makanan yang lebih disukainya terutama dari famili gramineae. Tanaman yang diserang adalah jagung, padi, sorgum atau spesies rumput lainnya.

PHT merupakan suatu metodologi yang mengandung prinsip-prinsip dasar yang menjadi pegangan para petani untuk menciptakan kondisi yang optima bagi lingkungan tanaman sehingga hama tidak menjadi masalah. PHT dapa mensinergiskan antara komponen pengendalian yang sesuai untuk lingkungan tertentu sehingga hasil pengelolaan menjadi lebih baik (cara pendekatan atau cara berpikir tentang pengendalian OPT yang didasarkan pada dasar pertimbangan ekologi dan efisiensi ekonomi dalam rangka pengelolaan agroekosistem yan berwawasan lingkungan yang berkelanjutan. Sebagai sasaran teknologi PHT adalah 1) produksi pertanian tinggi, 2) Penghasilan dan kesejahteraan petan meningkat, 3) Populasi OPT dan kerusakan tanaman tetap pada aras secara ekonomi tidak merugikan dan 4) Pengurangan resiko pencemaran lingkungan akibat penggunaan pestisida yang berlebihan.

Green Guard ${ }^{\circledR}$ merupakan bahan dagang bio-insektisida yang berisi konidia Metarhizium anisopliae var acridum (Deuteromycotina: Hyphomycetes) yang diproduksi untuk pengendalian populasi belalang kembara. Green Guard merupakan pestisida yang bersifat ramah lingkungan. Hasil uji coba di Australia, Cina dan Timor Leste cukup efektif dalam pengendalian hama belalang kembara. Di Australia umumnya pengendalian belalang menggunakan Metarhizium anisopliae var acridum (F1 985) (Milner, 1997).

Komponen pengendalian yang menjadi acuan dalam PHT salah satunya adalah pengendalian alami/hayati. Tujuan utama PHT pengendalian populas hama agar tetap berada di bawah aras yang tidak mengakibatkan kerugian secara ekonomi. Strategi PHT adalah penerapannya tidak menimbulkan kerusakan lingkungan yang merugikan bagi hewan dan manusia serta mikroorganisme lainnya baik sekarang maupun pada masa yang akan datang.

Budidaya sorgum yang dilakukan oleh petani selalu mendapat tantangan dari berbagai aspek gangguan serangga terutama hama belalang kembara. Terkait dengan adanya gangguan tersebut perlu dilakukan tindakan Pengendalian Hama Terpadu, untuk itu tujuan dari penelitian ini adalah mengidentifikasi hama pada tanaman sorgum dan mengaplikasikan bioinsektisida sebagai upaya pengendalian hama belalang kembara.

\section{Metode}

Penelitian dilaksanakan di pertanaman sorgum milik petani di Kabupaten Timor Tengah Propinsi Nusa Tenggara Timur dengan cara mengamati di lapangan, kemudian hama diperoleh dengan menggunakan metode light traps dan selanjutnya melakukan identifikasi di Laboratorium. Hama yang paling dominan dan paling banyak menyerang pada tanaman sorgum (hama belalang kembara) dapat diterapkan PHT dengan mengaplikasikan Green guard (beris Metarizhium anisopliae) yang diformulasikan dengan minyak nabati dengan tingkat perbandingan yang berbeda yaitu perbandingan GG 100\%, GG 1:50, GG 1:1000, GG 1:3000 dan kontrol (tanpa semprot). Perbandingan GG 1:50 dipersiapkan dengan mencampur GG sebanyak $2 \mathrm{ml}$ dengan $98 \mathrm{ml}$ minyak, GG 1:1000 dipersiapkan dengan mencampur GG sebanyak $0.5 \mathrm{ml}$ dengan $99.5 \mathrm{ml}$ minyak; GG 1:3000 dipersiapkan dengan mencampur GG sebanyak $0.15 \mathrm{ml}$ dengan $99.75 \mathrm{ml}$ minyak. Sebanyak 20 nimfa instar 3-4 kemudian dimasukkan ke dalam stoples plastik kemudian disemprot sebanyak 3 kali dan selanjutnya di masukan ke kurungan serangga yang berukuran $(30 \mathrm{~cm}$ x $30 \mathrm{~cm}$ x $30 \mathrm{~cm})$ yang telah disediakan pakan sorgum. Mortalitas belalang dilakukan pengamatan setiap hari hingga 14 hari setelah perlakuan. Rancangan yang digunakan dalam percobaan ini adalah Rancangan Faktorial dengan jumlah ulangan sebanyak 5 kali. 


\section{Hasil dan Pembahasan}

\subsection{Identifikasi Hama pada Tanaman Sorgum}

Hasil pengamatan di lapangan dan identifikasi serangga di Laboratorium menunjukkan bahwa terdapat sejumlah serangga yang bersifat sebagai pengganggu pada tanaman sorgum antara lain terdapat pada Tabel 1. Dari hasil pengamatan di lapangan menunjukkan bahwa jumlah populasi hama yang paling banyak pada tanaman sorgum adalah hama belalang kembara (Locusta migratoria, L). Kelimpahan hama ini disebabkan karena merupakan makanan kesukaan dan sangat baik untuk dimakan sehingga mempengaruhi populasi sangat tinggi. Selain itu hama ini mempunyai kebiasaan yang selalu bermigrasi apabila ketersediaan makanan berkurang dan dapat berkembang secara baik pada akhir musim hujan yang sebelumnya didahului oleh musim kemarau yang panjang. Hama belalang kembara yang tertangkap ini terdiri nimfa maupun imago. Belalang ini cenderung untuk membentuk kelompok besar dan suka berpindah-pindah sehingga dalam waktu yang singkat dapat menyebar pada areal yang luas. Kelompok yang bermigrasi dapat memakan tumbuhan yang dilewatinya selama dalam perjalanan. Perilaku makan belalang kembara dewasa biasanya hinggap waktu sore hari dan malam hari sampai pagi hari sebelum terbang. Kelompok nimfa yang bermigrasi dapat memakan tumbuhan di lokasi selama dalam perjalanan. Belalang ini lebih cenderung memilih makanan yang lebih disukainya terutama dari famili gramineae. Tanaman yang diserang adalah sorgum, jagung, padi, atau spesies rumput lainnya.

Tabel 1. Berbagai Jenis Serangga Hama pada Pengamatan Langsung pada Berbagai Umur Tanaman Sorgum.

\begin{tabular}{cllr}
\hline $\begin{array}{c}\text { Umur } \\
\text { Tanaman }\end{array}$ & \multicolumn{1}{c}{ Ordo } & \multicolumn{1}{c}{ Famili/Spesies } & $\begin{array}{r}\text { Jumlah } \\
\text { (Ekor) }\end{array}$ \\
\hline \multirow{6}{*}{ 28 HST } & Orthoptera & Locusta migratoria, L & 335 \\
& Homoptera & Cicadellidae & 32 \\
& Coleoptera & Chrysomelidae/Chaetocnema sp. & 45 \\
& Orthoptera & Grylidae & 76 \\
& Hemiptera & Alydidae/Riptortus linearis & 15 \\
& Hemiptera & Pentatomidae & 13 \\
& Orthoptera & Tetrigidae & 89 \\
\hline \multirow{6}{*}{ 49 HST } & Orthoptera & Locusta migratoria, L & 200 \\
& Homoptera & Cicadellidae & 21 \\
& Coleoptera & Chrysomelidae/Chaetocnema sp. & 28 \\
& Orthoptera & Grylidae & 33 \\
& Hemiptera & Alydidae/Riptortus linearis & 43 \\
& Hemiptera & Pentatomidae & 22 \\
& Orthoptera & Tetrigidae & 58 \\
\hline \multirow{6}{*}{ 70 HST } & Orthoptera & Locusta migratoria, L & 233 \\
& Homoptera & Cicadellidae & 45 \\
& Coleoptera & Chrysomelidae/Chaetocnema sp. & 21 \\
& Orthoptera & Grylidae & 76 \\
& Hemiptera & Alydidae/Riptortus linearis & 56 \\
& Hemiptera & Pentatomidae & 35 \\
& Orthoptera & Tetrigidae & 67 \\
\hline Sumber: Analisis Identifikasi di Laboratorium Entomologi UGM, 2016 &
\end{tabular}

\subsection{Aplikasi Bioinsektisida pada Hama Belalang Kembara}

Pada Gambar 1. menunjukkan bahwa tingkat kematian nimfa tertingg terjadi pada semua konsentrasi, tetapi pada kontrol (tanpa Green Guard dan tanpa minyak) juga menunjukkan bahwa tingkat kematian nimfanya sedikit. Pada konsentrasi $100 \%$ dapat mematikan nimfa belalang kembara lebih tinggi dibanding dengan konsentrasi lainnya.

Semakin tinggi konsentrasi jumlah belalang yang mati semakin meningkat baik dan jika konsentrasinya menurun maka jumlah belalang yang mati akan sedikit. Pada tingkat konsentrasi $100 \%$ jumlah nimfa yang pada hari pertama setelah aplikasi tingkat kematiannya lebih dari 30\% sedangkan pada konsentrasi lainnya tingkat kematian berkisar 5\% sampai $10 \%$, pada kontrol kematian nimfa $0 \%$. Pada konsentrasi $100 \%$ jumlah nimfa yang mati dicapai pada hari kedelapan setelah aplikasi Green guard, sedangkan tingkat konsentrasi 1:50, 1:1000 dan 1:3000 jumlah nimfa yang mati dicapai pada hari keempat belas setelah aplikasi dengan persentase kematian 90-100\%. Pada kontrol (tanpa disemprot) tingkat kematian nimfa berada di bawah tingkat kematian $20 \%$.

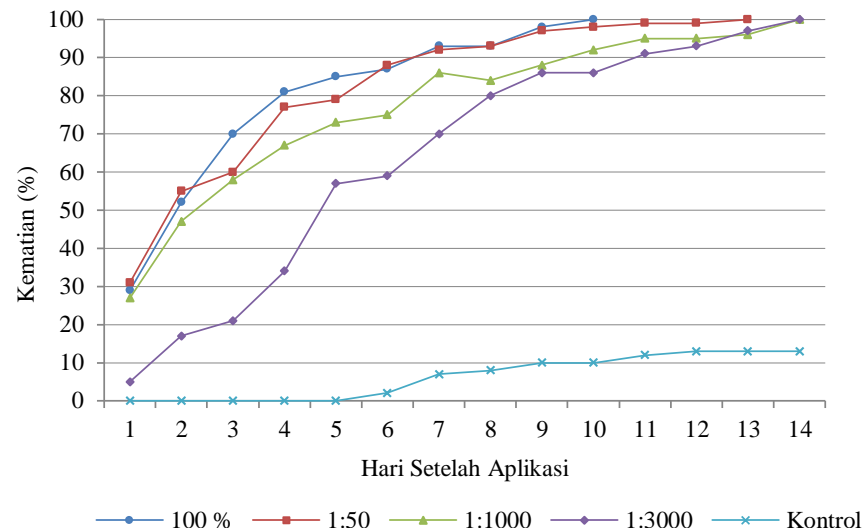

Gambar 1. Pengaruh Mortalitas Hama Belalang Kembara Dengan Tingkat Perbandingan Konsentrasi Green guard Yang Berbeda Pada Minyak Nabati

\section{Simpulan}

PHT merupakan suatu metodologi yang mengandung prinsip-prinsip dasar bagi para petani dalam menciptakan kondisi yang optimal bagi lingkungan tanaman sehingga hama tidak menjadi masalah. Salah satu metode PHT yang digunakan untuk pengendalian hama khususnya hama belalang kembara adalah menggunakan green guard (berisi Metarizhium anisopliae, L) yang cukup efektif dan bersifat ramah lingkungan.

\section{Pustaka}

Batan Teknologi, 2013. Uji Coba Budidaya Sorgum Di Kabupaten Belu, Timor Tengah Utara dan Malaka.

Milner RJ, 1997. Metarhizium flavoviridi (F1985) as apromising mycoinsecticide for Australian acridides. Pp 287-300. In: Microbial Control of Grasshopper and Locusts. Goettel MS, Johnson DI (Eds) Memoir 171 of the Entomological Society of Canada.

Rukmana, R 1994. Budidaya Sorgum. Kanisius. Yogyakarta

Sirappa M.P. 2003. Prospek pengembangan Tanaman Sorgum di Indonesia sebagai Komoditas Alternatif Bahan Pangan dan Industri. 